\title{
Discourses, practices and performances in Sámi museology at Tromsø University Museum
}

\author{
Rossella Ragazzi \& Giacomo Nerici
}

\begin{abstract}
This article focuses on the set up, reception, and social scientific discursive fields that have informed two exhibitions about Sámi culture curated over time by Tromsø University Museum. They were curated in two different periods in the recent history of the Sami (end of 1990s and 2013-15). In our anthropologicallyinformed analysis we take a second look at the way in which researchers and curators have constructed, performed, and narrated certain aspects of Sámi material and immaterial heritage, in times of change and political awareness. The recent exhibitions have contributed to articulate essential issues concerning ethnic identity and cultural belonging in conversation with or critique towards the previous representation of Sámi ethnography at the museum, especially the renown Sámekulturen curated by Ørnulf Vorren. How did these exhibitions handle the representations in which Sámi people would mirror their history, identity and aesthetics? How did they speak on behalf of the Sámi but also in conversation with the Sámi? How were these presentations interpreted over time in a changing museological practice?
\end{abstract}

Keywords: Sápmi, Samekulturen, Sápmi - Becoming a Nation, Critical Museology, Sámi Stories, Tromsø University Museum, Ø. Vorren, H. Eidheim, Cultural Belonging, Indigenous.

The Tromsø University Museum has curated two permanent exhibitions and one major traveling exhibition about Sámi culture in three different epochs. It is hence interesting to study them in relation to each other, and to individuate some of their discursive paradigms: the critique of "ethnographic description" through the lenses of processual anthropology and the musealization of the aesthetics of activism in Indigenous art. This article focuses on the set up, reception, and social scientific discursive fields that have informed the two latest exhibitions about the Sámi curated over time by Tromsø University Museum. They were curated in two different periods in the recent history of the Sámi (end of 1990s and 2013-15).

The exhibition Samekulturen (The Sámi 


\section{Discourses, PRACTICES AND PERFORMANCES IN SÁMI museology at Tromsø University MUSEUm}

Culture) was opened in 1973 at the Troms $\varnothing$ Museum, and its main emphasis was on Sámi material cultural heritage, attempting to include every form of social life in order to salvage what was perceived as being on the edge of disappearance (see Fonneland's article in this volume). The main curator, professor Ørnulf Vorren (1916-2007), whose disciplinary involvement in Sámi culture was more than three decades old at that time, tried to handle the social and cultural problems of the Sámi without really talking about it directly. It was a time where the Sámi had been assimilated to the mainstream Norwegian culture, and where the stigma of belonging to a minority was not a theme for an exhibition. The material repertoires told in the "ethnographic present" appeared as preserved from the disruptive character of modernization. (Fig. 1).

When the Sápmi - en Nasjon blir til (Sápmi Becoming a Nation) exhibition opened at Troms $\varnothing$ University Museum in 2000, it distinguished itself from its predecessor in terms of set-up, plot, and communication strategies, but also performative aspirations. The theme of the exhibition was the narrative of contemporary events that, from World War II to the present, made possible the emergence of the Sámi nation. The original idea for the exhibition was conceived by anthropologist Harald Eidheim (1925-2012), who had been professor at the University of Tromsø and Oslo, and was part of the processual turn in anthropology, in conversation with Frederic Barth and Robert Paine. Eidheim was at the time visiting professor at the Sámi Ethnographic Unit of the museum. The curators ${ }^{1}$ chose a set-up where the visitors could interact with some of the devices, "gaining insight into how museum presentations can be seen as a dialogue - or negotiation - with audience" (Eidheim et al. 2012:107).

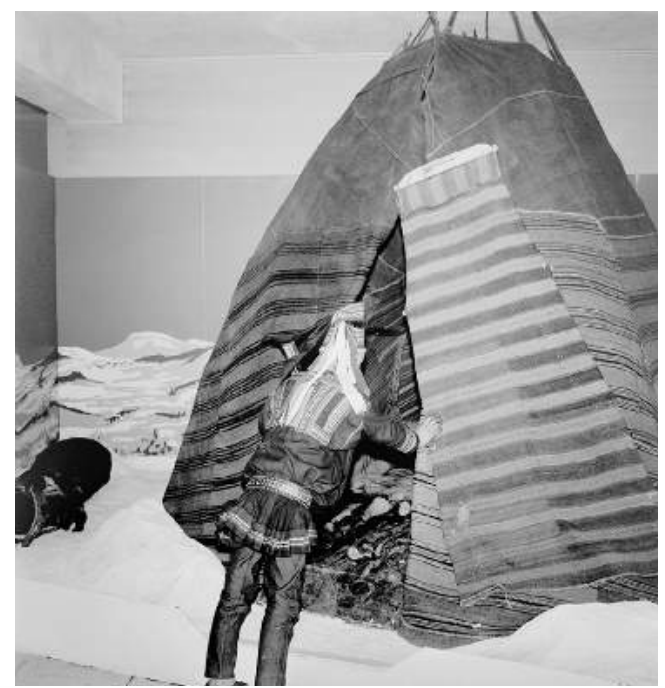

Fig. 1. Exhibition Samekulturen, 1972. A primary school class from Máze visits the exhibition. Photo: Olga Kvalheim, Norges arktiske universitetsmuseum.

Sápmi - en nasjon blir til emphasized the discourses initiated two decades earlier by the New Museology movement. Dissemination of knowledge was implemented through visual literacy, websites, and other types of lay-publications, courses, and educational activities. All these aspects gave the opportunity to involve the visitors in the museum activities "bridging the gap between professionals and non-professionals" (Kreps 2003:10) and making them "crucial participants in the process of meaning-making" (Rhiannon 2006:27).

The team of curators of Sápmi - en nasjon blir til, after some hesitation, decided to keep Samekulturen on display even if it was somehow an old representation. They did it in order to give a sense of the genealogy of academic museum's presentations, and to create a contrast and complement with Sápmi - en nasjon blir til. In this way, these two permanent 
136 exhibitions became "conceptualized archives" standing for the discursive fields that produced them. Hence, maintaining both exhibitions side by side at the Tromsø University Museum creates a comparison between two different ways of representing Sámi culture. By the same token, it leads to a meta-level of interpretation about how exhibitions present, represent, and construct their subjects. Their association in a specular symmetry (left and right aisles of the museum's second floor) becomes a sort of stereophonic device in which the old and the new may possibly dialogue.

Sámi Stories, the third major Sámi exhibition that Tromsø Museum opened in New York, at the Scandinavian House in 2014, was a traveling exhibition based on the permanent exhibition Sápmi - en nasjon blir til. It was a collaboration with the Northern Norwegian Art Museum, and it combined some of the features of the other two exhibitions, including anthropological inflected banners with informative texts, several ethnographic masterpieces from Tromsø Museum collections, and a new section profiling iconic contemporary artworks that are peculiar of Sámi innovative aesthetics (Gullickson \& Lorentzen 2014). The conversations with the curators, the participatory observation during the set-up, interviews with audiences and the study of the catalogues of this major exhibition have been a crucial approach in reading Sámi Stories.

The last section of this article is dedicated to our attempt to understand how these three exhibitions negotiate meanings with the public in the practice of fruition. The methodology adopted for our investigation firstly required an in-depth study of the archive sources and of the objects and registers used in the exhibitions. At the same time, our choice was to interact with the curators and museum staff through interviews and personal conversations in order

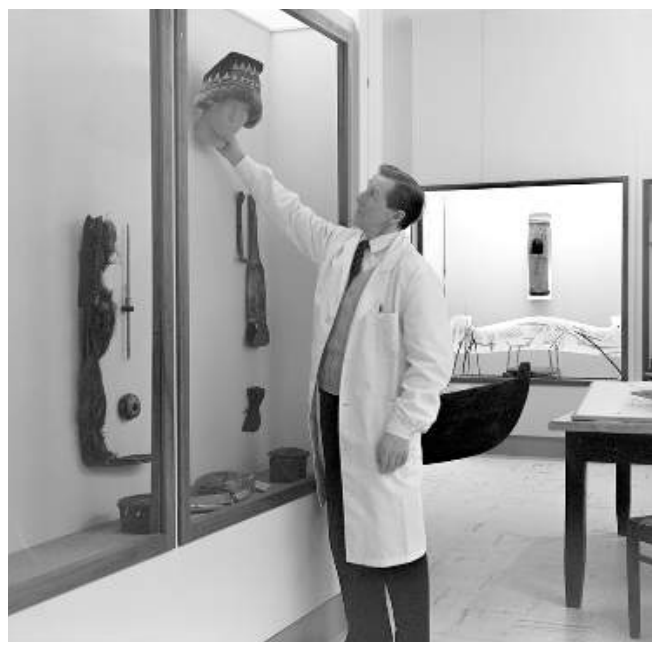

Fig. 2. Professor Ørnulf Vorren mounting a glass case in Samekulturen, 1971. Photo: Olga Kvalheim, Norges arktiske universitetsmuseum.

to deepen specific topics. Last but not least, we concentrated on the experience of the visit, both actively participating in guided tours and compiling and analysing questionnaires with the aim of understanding the motivations, the expectations, and the points of view of the visitors of these exhibitions.

\section{IN CONVERSATION WITH THE PAST}

The exhibition Samekulturen was translating and reproducing, in museological form, the all-encompassing Sámi ethnography that had been investigated in the homonymous book Samekulturen (1957) that Vorren co-edited with the Swedish ethnographer and mentor Ernst Manker. ${ }^{2}$ (Fig. 2).

The exhibition managed to establish a collaboration with the public sphere and constituted, for several generations of Sámi, a medium to learn and become proud of their own cultural history. Over time, it became also 
a repository to draw on, for touristic guides and marketing, where images like reindeer herding became iconic or stereotyped (Eidheim et al. 2012:103).

Through the lenses of processual anthropology, salvaging material repertoires in the ethnographic museums meant to defend the traditional aspects of Sámi culture against the subversive character of modernization. The nostalgic tone which celebrated the purity of a past destined to disappear, associated with a detached and all-encompassing ethnographic gaze, dissimulated a power position, which was almost unavoidable when collecting and "musealizing" objects belonging to an Indigenous people (Clifford 1988). Vorren selected among the elements of the tradition what the public was supposed to associate with the concept of "Sámi culture". The set-up was conceived as a representation of alterity through a temporal dislocation (Fabian 1983). The confinement of objects in a time "other" reveals the epistemological frame in which Vorren acted as scholar. The narrative results are somehow static and narrated through the usage of the "ethnographic present", situating the content in a time without history. The tools, implements, dioramas and old black and white photos of subjects captured in their everyday life, seem to enhance some nostalgic aspects of Sámi culture and emphasize the idea that progress is condemning this population to a loss of authenticity. (Fig. 3).

The tone of the exhibition is explanatory, the content is presented to an audience basically not informed enough, and which seems not to have been involved in the production of meaning (Hooper-Greenhill, 2003). In the first glass case of the exhibition, a series of historical references, maps, and documents synthetize the beginning of the first chapter of Manker \& Vorren's book (1957), revealing how the

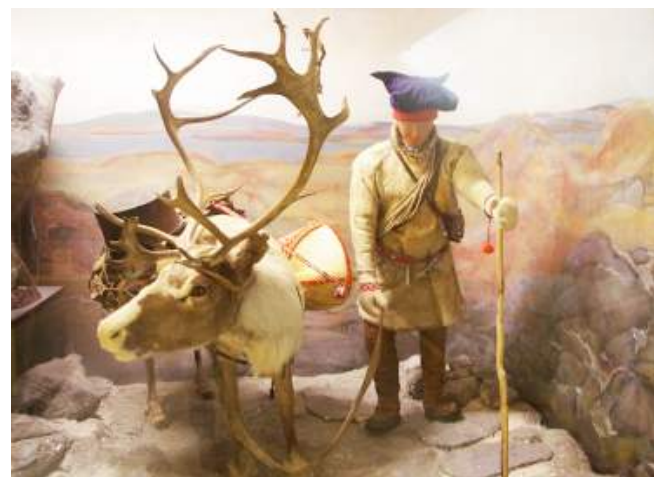

Fig. 3. One of the dioramas in Samekulturen showing the relation between the Sámi people and the reindeer. Photo: Giacomo Nerici.

exhibition, from now on, will museologically translate a "text-book" (Mathisen 2004). In reality, when Vorren designed the presentation, he wanted to emphasize the existence of Sámi in the subarctic areas for many thousands of years. He wanted to use historical evidence to show that Sámi inhabited these regions in their full right. This fact is still controversial for many Scandinavians and Finns, because the Sámi people were not considered as "subjects of history" in the time when Vorren initiated the exhibition project.

Although Samekulturen has been kept beyond its due time, nowadays many consider its outlook to be charming rather than obsolete. If it holds its aesthetic qualities until today, it is especially because of the contribution of Iver Jaks, an artist who saw the design as an artefact in its wholeness. Forms, colors, serigraphs, drawings, and the levity that the whole scenery possesses, makes the narrow space with the objects, stuffed animals and dioramas still admired today. The pastel colors in beigeyellow-grey, on the cabinets and on the walls, make the strong tones of the Sámi outfits stand out and shine. With its emphasis on materiality 
and heritage, Samekulturen appears today very precious in the comments of many visitors, even more so because the items on display are among the finest in Sámi exhibitions worldwide. To conclude, on the one hand, the exhibition represents a precious repository of artifacts and information on traditional culture that are still indispensable today and, on the other hand, it offers an indispensable term of comparison to understand the epistemological frames that generated them. (Fig. 4).

\section{SÁPMI EN NASJON BLIR TIL}

The first decade of the new millennium has seen curatorial practices and museological trends, museum technologies, media and the democratization of interaction within museums evolve rapidly from what was called New Museology (Vergo 1989). ${ }^{4}$ This approach stresses the importance of community participation in the construction of museum representation and interpretations of meanings (Kreps 1998:13). Museological politics of knowledge in the last two decades have modified the role and authority of experts, collaborating with the producers of "authorized" knowledge. On the one hand, this process led to widening intercultural relationships from those established solely around collecting and displaying, to include related issues of restitution, cultural management, and the museum's wider political integrations (Shelton 2006:77). On the other

Fig. 4. River Sámi displays in Samekulturen, set-up by Iver Jåks. Photo: June Åsheim, Norges arktiske universitetsmuseum.

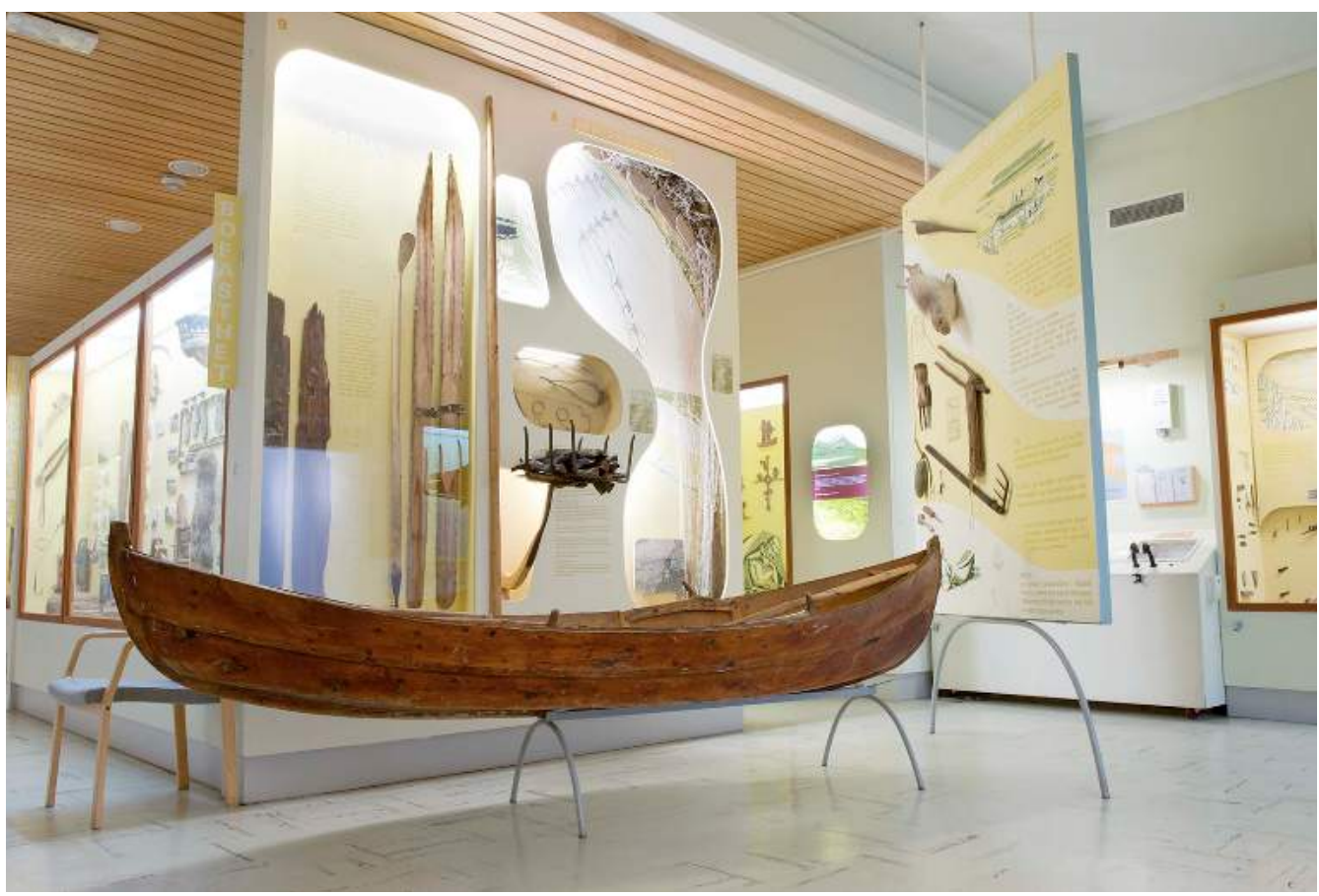


hand, museums became "contested arenas" where various communities debate what culture is, how it should be represented, and who holds the power to represent it (Karp \& Levine 1991; Karp et al. 1992). When the museological paradigms expressed by Samekulturen encountered an epistemological reconfiguration, the team of anthropologists working in the museum (Vorren had by then retired) started to plan a new project for a major Sámi exhibition, which opened in 2000, namely Sápmi - en nasjon blir til.

This new exhibition took as its main theme the ethnopolitical processes of emancipation of the Sámi people of Norway, spanning from the post-World War II period to the end of the millennium, focusing on the socio-political discourses that led to the establishment of the Sámi Parliament in 1989. The curators who had been involved in some of the major historical events profiled in the new exhibition, wanted to try out a museological narrative as a form of cultural critique (Ragazzi 2008:103). ${ }^{5}$ The project was discursively influenced by processual anthropology theories" ${ }^{6}$ and "was intended as a means of correcting public narratives of the Sámi" (Bjørklund 2000:1). The main curators Harald Eidheim, Terje Brantenberg, and Ivar Bjørklund had participated in the consolidation of Sámi studies at the department of social anthropology at the University of Tromsø, having closely followed questions of customary law, ecology of reindeer-herding, and Indigenous rights. Hence, a political dimension in the presentation of ethnography was taking hold at Tromsø University Museum for the first time.

Sápmi - en nasjon blir til was the first exhibition that featured the word "Sápmi" in its title, which is a central concept in the development of the modern Sámi ethnopolitical movement. "Sápmi" is here intended as a nation without borders and statehood and it is referred to as the territorial, social, and cultural community of the Sámi who live in the northern parts of Fenno-Scandia. The items on display includes an abundance of archival material, pictures, a series of interactive videos, a special issue of the museum journal Ottar, a catalogue, items of popular culture, banners and political illustrations, and a few objects. The translation of the captions is in three languages (Norwegian, North Sámi, and English) and of 60 items displayed, only two present a written description, while of the nearly 80 photos and illustrations, none of them have an explicatory caption (Eidheim et al. 2012:107). To interpret their meanings, one must contextualize them inside each respective room and as a part of the whole historical and social context of the exhibition, for which the information is provided by the booklet (Bjørklund 2000). ${ }^{7}$ A further interpretation is then given by the guides that can offer a synthesis that is adapted to the context of reception (Nerici 2019). In fact, rather than preferring a curatorial style centered around ethnographic items, the choice was to show the curators' interpretation of what led to the realization of "Sápmi" through a multitude of references, connections, and contrasts (Eidheim et al. 2012:97).

The conceptual design chosen for the set-up did not aim to be a mere aesthetic solution, nor an exercise of extravagant formalism. Installations, audiovisual devices, and interactive media were chosen to facilitate the experience and fruition of heterogenous visitors, with whom the museum wished to communicate in the future. The imagined visitor was an educated adult intended to creatively elaborate his own interpretative strategies interacting with the exhibition (Hooper Greenhill 2003). In other words, the 
140 latter turns the visitor into an active protagonist because the representations were considered as "context of reception's dependent" (Ragazzi 2008:101).

Sápmi - en nasjon blir til, to the best of our knowledge, is also one of the first exhibitions where a contemporary Indigenous movement is profiled as protagonist. Curators, aware of the multiple discourses at stake, are taking on the burden of such "successful" narratives, and they are not exempt from criticism for being biased, having refused a more neutral positioning (Clifford 1988). In fact, the criticism raised by some after the opening emphasized the political role of the curators, disguised behind the feature of a narrative that "objectively wrote itself" but that actually hid their own authorial interpretation and protagonism in the events profiled (Mathisen 2001:44).

However, in contrast to the USA, Australia or Canada, where the relationships between Indigenous communities and the state are more often conflictual, if not violent, those ones that occur between the Sámi and the Norwegian State are less tense and facilitated by the role of the Sámi Parliament and Sámi Council of Culture. In fact, the presence of "a consultative team of Sámi as Indigenous representatives” to monitor the exhibition was considered unnecessary by Eidheim and his colleagues, even more because the Sámi Parliament had approved the project description before the set-up started (Eidheim et al. 2012:112-113).

Despite the originality of the topic, it was not easy to stimulate feedback from the Sámi establishment in the first years following the opening. Press coverage diminished after the curiosity of the opening year and some scholars wrote critically about it. It took some time before it could turn into an effective tool for dissemination of knowledge. It happened, indeed, especially because its curators and their assistants endured to guide and publish on it a long time after its opening. The public and scholars began using the resources available to them in the following ways; external researchers were encouraged to study it as an unprecedented endeavor in "museological" ethnopolitics; students from the university visited and actively used its resources for their theses; master courses were held at the museum with the exhibition as laboratory (Ragazzi 2008). Moreover, international visitors appreciated its novelty as hundreds of comments show in the guest books. Importantly, Sámi and Indigenous delegations visited it obligatorily when coming to Tromsø University. In this way, from a temporary exhibition lasting five years, it became permanent, not only because of a selfimposed necessity (it worked well, after all, and the museum could not produce so many major exhibitions so often), but because it renewed and expanded its relevance, also inspiring curators in other Sámi museums, or other museums treating Sámi topics, in Scandinavia and Finland.

The main set-up of the introductory room is comprised of eleven large-size portraits displayed on the walls, depicting men and women with no particular distinctive elements that make them recognizable as Sámi (with the exception of one woman sitting on a snowmobile with a reindeer fur overall, that makes her recognizable as a herder). For each portrait, a wooden box is attached underneath, showing through a porthole one item that is supposed to belong to the corresponding portrait: it can be a tool, a children's book, an ornament, a mysterious daily object, whose relation to each subject can only be imagined or speculated.

Curators do not use an explanatory mode, 


\section{Discourses, PRACTICES AND PERFORMANCES IN SÁMI museology at Tromsø University MUSEUm}

but they wish to evoke, through references, allusions and free associations of ideas, the significance of each given coupling between a portrayed person and his-her chosen personal item. (Fig. 5).

Postures and mimics restitute ordinary profiles of people who are no longer obliged to pose in such a way that satisfies a need for exoticism, or to pose as a witness to their own alterity. Challenging the audience to recognize the ethnic identity of these subjects, the exhibition attempts to overturn essentializing icons that museums and academies have contributed to creating in the past, and that today are still circulating in the world of consumerism.

Two computers make it possible to listen to the biographical accounts of several Sámi people which relate to general questions each individual is invited to problematize. Through this multimedia expedient, the voices of the social actors break into the exhibition, interacting directly with the public. Despite the communication being structured in a rigid frame in which the protagonists can only briefly answer certain questions posed by the curators, the paradigm shift in the relation between audiences and cultural subjects is pretty radical when compared to Samekulturen, where the social actors were reduced to mere nameless figures, deprived of their own voice, and mostly featured to reinforce the ethnographers' discourses.

One of the most iconic moments in the exhibition is the final room where on display is the Constitution paragraph 110a (1988), leading to the establishment of a Sámi Parliament in 1989. This celebratory closing of Sápmi - en nasjon blir til usually fascinates even the most reluctant visitors because it celebrates the adhesion of legal protection for the Sámi people - a people who shall thrive

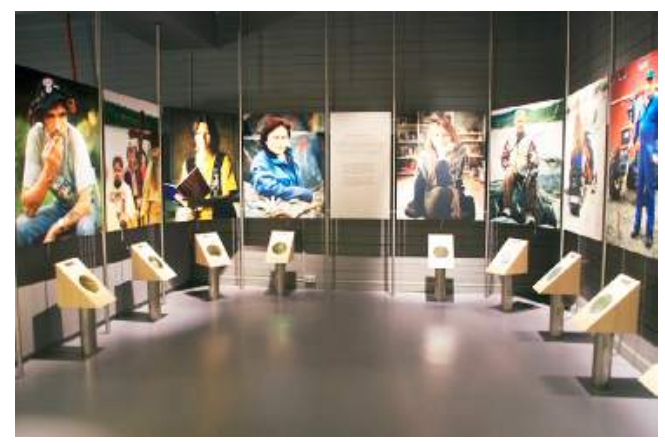

Fig. 5. The exhibition Sápmi - en nasjon blir til: The introduction room and the portraits. Photo: Giacomo Nerici.

and be recognized for their languages, style of life, values and sustainability. What is utterly important is that they are referred to as "a people", and not merely "a population".

This caption with the paragraph of the Norwegian constitution is set on a graciously curved wall at the end of the exhibition; on the wall there is a monumental photograph (which is cropped from its original) which shows a Sámi woman holding a Sámi flag in the posture of a French Revolutionary Marianne. It was taken in Oslo in the 1990s, during the celebration of one of the most monocultural events of the year: the 17th of May parade. ${ }^{9}$ (Fig. 6a).

Harry Johansen, a photographer and filmmaker from the Tana region, explained that "the first time that somebody saw the Sámi flag at the 17th of May Parade in Oslo" (Johansen 2015) was in 1992 when he had travelled to produce a multimedia advertisement for the Sámi Parliament.

Days before the national day celebration, he made up a plan to shoot the advertisement involving Máret Guhtor and Roger Ludvigsen, using a $300 \mathrm{~mm}$ lens and walkie talkies, since there were no cell phones back then. Standing 


\section{Rossella Ragazzi \& Giacomo Nerici}

142

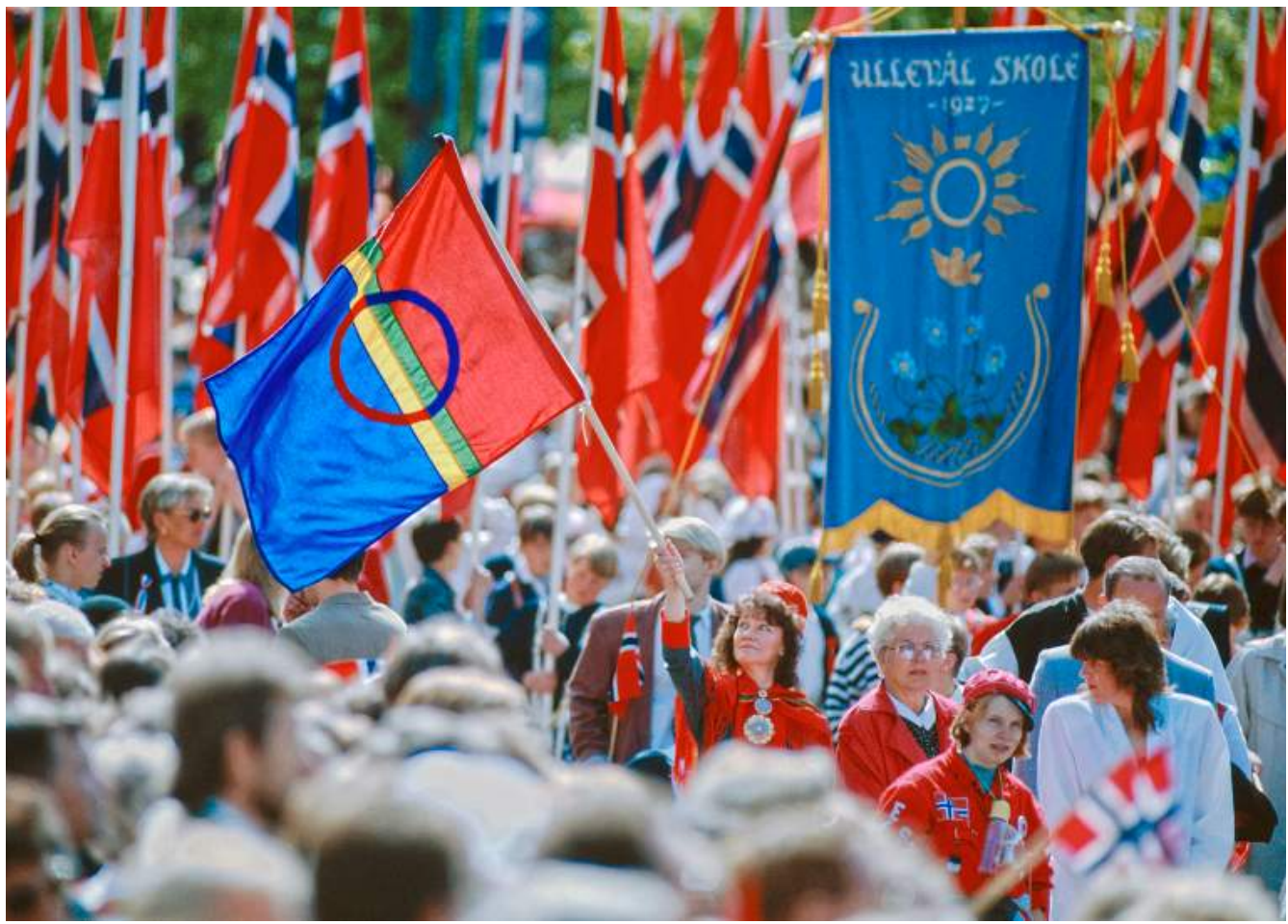

Fig. 6a. Photo (original frame): Harry Johansen.

by the royal castle in Oslo, he had told Máret to leave the sidewalk and enter the parade, majestically deploying a Sámi flag. Which she did, but the whole procession behind her stopped, and an onlooker supposedly said: "Look, the Sámi are demonstrating again!" Harry was simultaneously taking photos, but a uniformed policeman came and told him sternly to leave the spot immediately. He had therefore to call the others to come out, for the job was done: "That picture is now hanging at Tromsø Museum, as part of the exhibition Sápmi - en nasjon blir til" (Johansen 2015).

However, this image is not contextualized with any caption that explains the story behind it because the curators themselves did not know it had been staged. Hence, one can wrongly believe that the Sámi flag was authorized in the 17th of May parade without any problems then. On the contrary, several controversies have been debated in the years prior to and after the early 2000s, these debates were whether the Sámi flag should be accepted or refused in several municipalities. "When items are particularly iconic, or considered to have symbolic authority, the ability to control or influence how those objects are understood is important in the politics of community and group representation" (Smith 2006:263). (Fig. 6b).

The last room of Sápmi - en nasjon blir til, where the photo discussed above towers, is the conclusion of a path reconstructed 
through a stratification of experiences and historical moments that here seem to find their redemption. Archeologist Bjørnar Olsen remarks (2000:21) that this narration maintains a classic plot in its original style and content. In other words, the exhibition recomposes incoherent fragments of the past into a discursive narrative that make them part of an accessible story with even some romantic nuances: a heroic realization starting from a negative beginning until the final redemption. On the wall there is a miniature model of the wooden Sámi Parliament in Karasjok, and beside it is a suitcase filled with administrative documents, leaflets, and paperwork of various kinds, which point to such a narrative of redemption: "The suitcase of Ivar Simonsen, Bjerkvik. NRS representative at the Sámi Parliament, 1989-1993" says a label. The reference, highly symbolic, tells how the presence of Sámi people, from insignificant, disunited, and marginal, have reached success affirming themselves in a political and constitutional frame, all thanks to a representative body. If until that moment it was the singular initiative or small committees that supported the struggle for an identity appropriation, now the duty was undertaken by an official institution whose governance is Indigenous. This seems to demonstrate how the Sámi have grounded their presence in an institutional frame that enshrines their visibility, both within and outside of the national borders. The images chosen in that room of Sápmi - en nasjon blir til, can be read as a sensible frame in relation to the portraits exposed in the introductory room. In fact, it seems that the visitors, after having experienced a cumulative historical account, can finally recognize the political, social and cultural background in which those portraits moved in the then contemporary society.

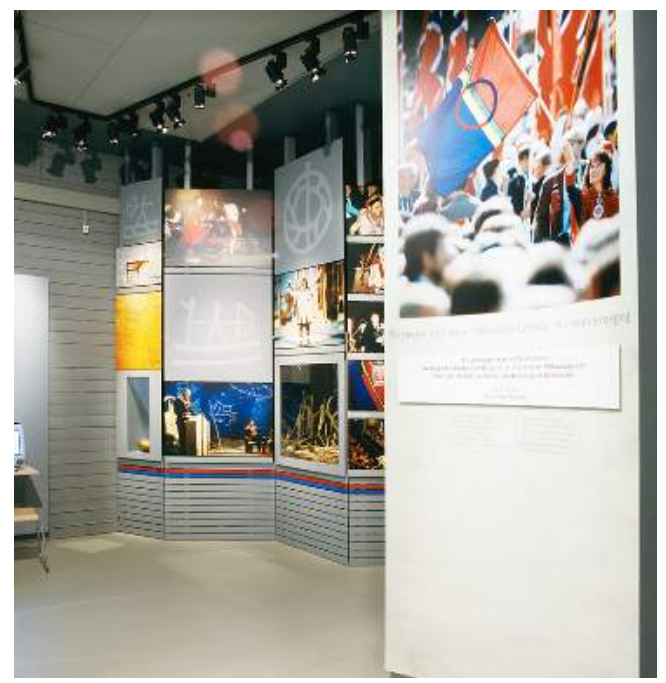

Fig. 6b. Johansen's photo as it is displayed in the exhibition Sápmi - en nasjon blir til. Adnan Icagic, Norges arktiske universitetsmuseum.

\section{SÁMI STORIES}

In the contemporary moment, exhibitions have explored and widened their politics of display, departing from previous decades where "objects" were not deemed to be so central to new ways of performing materiality through interventions of artists, or art curators. "We" as a unifying and inclusive designation, became gradually more prominent than "The Others and Us" or other dichotomizing expressions such as "the West and the Rest" (Hall 1992). This stance informed the ethics of representation and the role of the museum in impacting society "not solely through the objects but, more importantly, with ideas - notions of what the world is or should be" (Lidchi 1997: 160). (Fig. 7).

Sámi Stories (2014) was born out of the wish of the curators of Sápmi - en nasjon blir til to create an international traveling version of it. The then director of Tromsø University 


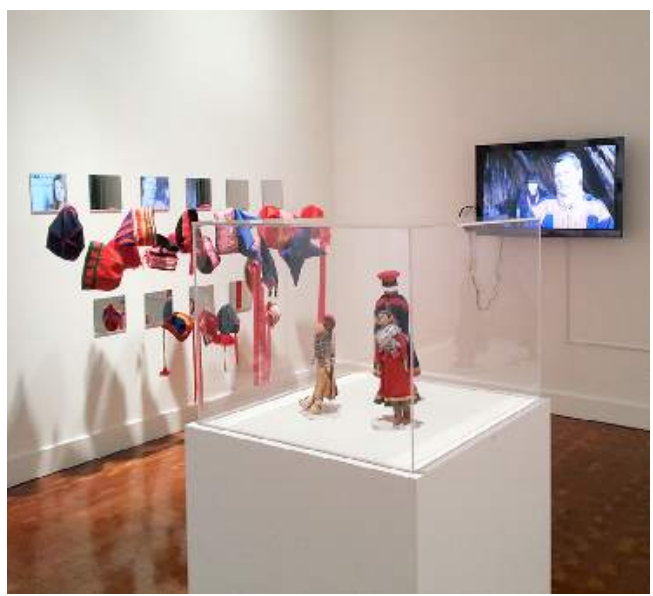

Fig. 7. New York, 2014. Sámi Stories: Photo: Rossella Ragazzi.

Museum, folklorist Marit A. Hauan, took the initiative to support their wish and she came on board and also involved the Northern Norwegian Museum of Art and its curator Charis Gullickson. Another collaboration was established with the Centre for Northern Peoples/Senter for Nordlige Folk in Manndalen.

Out of this synergy, Sámi Stories includes, beside ethnographic objects, a major section of contemporary Sámi art as well. A rich catalogue in two volumes also accompanies the exhibition whose imagined audience is educated, cosmopolitan, international, Indigenous-friendly, and English speaking. The project was launched and financed during the Norwegian Constitutional Jubilee, "an occasion for a massage of our national muscles for setting the Sámi nation on the table" (Hauan, personal communication 2018). Norway has one of the oldest constitutions in the world and concerning Indigenous issues one of the best: the paragraph $\$ 118$ (previously titled 110a) vernacularly known as the "Sámi paragraph" offers a unique definition of Indigenous and Minority rights. ${ }^{10}$

The curators belonged to two main disciplinary fields: ethnography/ethnology, anthropology, and history of art and craft. In the beginning, they thought to keep the two different topics separateed, one ethnographic and the other devoted to art. However, they progressively realized that they could echo each other because of Sámi materiality and heritage itself (Hauan: p.c. 2018). They felt that the material culture aspects of Sápmi - en nasjon blir til were not highlighted enough, and so they decided to choose among the most prominent ethnographic items of the Tromsø University Museum Sámi collections (Storm \& Isaksen 2014:91): three old dolls, a fine milk bowl, a knife, a baby cradle and the rare ceremonial drum normally exhibited in Samekulturen. Despite several newly-made Sámi hats were ordered from expert duojar (Sámi artisans), the artefacts of Vorren's exhibition has a central role in Sámi Stories because the curators wanted to underline a precise continuity with past by giving a different frame and new meanings to traditional objects of Samekulturen.

The curators considered the genealogy of the various major Sámi exhibitions in their museum, looking retrospectively to their predecessors, to the references that the two exhibitions in the museum had generated. To know that, as Hauan says, "Iver Jåks had drawn the milk bowl dozens of times, until it became perfect" gave them the inspiration to pay respect to the multiple forms of art that are not highlighted in mainstream art history (Guttorm 1999). The elements that are so present in Sámi material life: leather, wood, textile, and especially the round forms (drum, milk-bowl, cradle and jewels) were thought through carefully and given variations in form 


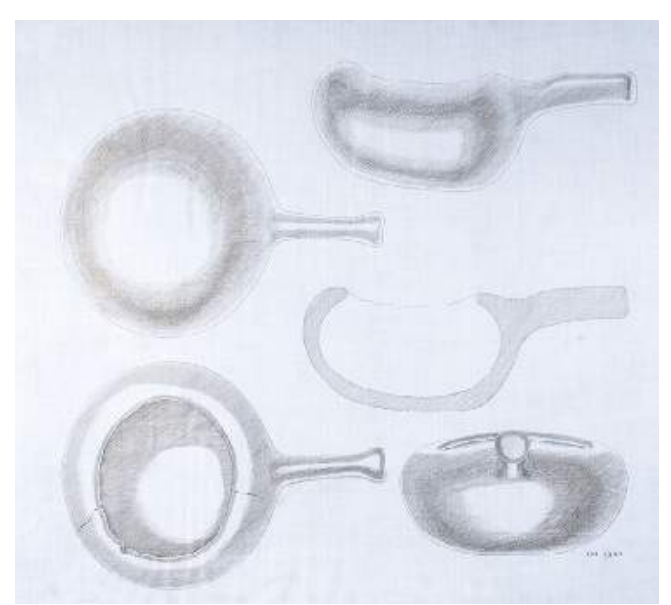

Fig. 8. Iver Jåks, preparatory drawings for the exhibition Samekulturen. Photo: Olga Kvalheim, Norges arktiske universitetsmuseum.

and materials. The stages of life were also brought in: childhood, adulthood, elderly time (Oskal 2014). (Fig. 8).

Sámi Stories was intended to travel and to be shown in New York, Anchorage and Tromsø, each time with correlating seminars, performances, workshops, concerts and screenings of Sámi films. The itinerant character of this exhibition calls to mind the so-called "objets ambassadeurs". ${ }^{11}$ These types of artefacts are intended to travel around the world with the idea of enabling knowledge about Kanak culture by means of a wandering heritage, unbound from a specific museum infrastructure that must return to "regenerate" and then leave, continuing to feed new and old bonds (Paini \& Aria 2014: 10). Similarly to the travelling objects of the Kanak people, the items on display in Sámi Stories belong to the new revaluation of materiality, the "thing-turn", a way of conceiving the artifacts themselves as "contact zones" (Clifford 1997). They enact the knowledge(s) that created them, whose materiality and intangibility they embody, and simultaneously, they are agents for new relations, events, and stories. To display is not necessarily only presenting, but also to realize, to reveal something that the materiality and cultural specificity of the subjects in display are able to manifest and eventually impose from inside their cultural universe. Curators who are able to listen and see these signs are then opening for an explorative practice in their work. This realization can lead to decolonizing collections.

In this line, Sámi Stories became a unique endeavor in the chain of the three exhibitions. The choice of "fusing" the two main aspects of Samekulturen and Sápmi - en nasjon blir til by enlarging the ethnographic display with works of Sámi art, and with documents and texts about the emancipatory history of Sámi people, gave rise to an expansion of horizons from different audiences. Moreover, it seems that it rendered more visible some of the cosmopolitan aspects of Sámi material culture (Gullickson \& Wei-Hsin Din 2015). When asked what she thinks was missing from Sámi stories, Hauan said that the geopolitical dimension is not treated as it should and she regrets it. Although the two long videos with Ole H. Magga and Mari Boine presented in the exhibition treated the important topics of politics and music, these themes are not really appearing in other sections of the exhibitions, nor is literature and poetry, which are also very important expressions of the contemporary Sámi culture. Thus, as Hauan stated, if she had to redo the exhibition, these aspects would be much more prominent, together with bringing the work of younger Sámi artists and poets into display. This curation took for granted that cosmopolitanism is the new arena for Indigenous questions, and certainly the Sámi were from early on in the Indigenous 


\section{Rossella Ragazzi \& Giacomo Nerici}

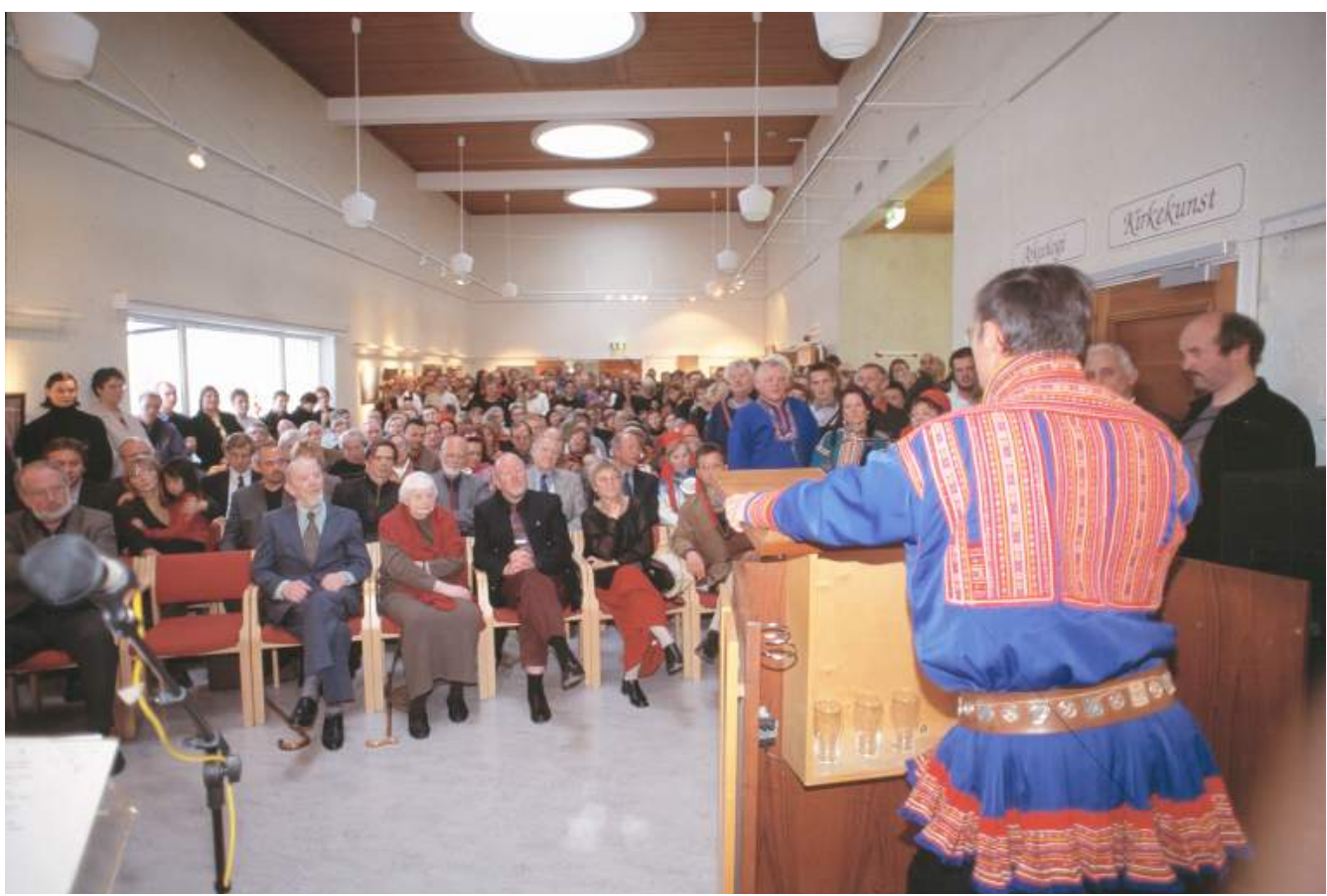

Fig. 9. Ole Henrik Magga, former President of the Sámi Parliament, held a speech at the opening of Sápmi en Nasjon blir til. Photo: Adnan Icagic, Norges arktiske universitetsmuseum.

movement. They still are among the most internationally active promoters of political action in a "pan-Indigenous" perspective, even if this is not the only reality of most of Indigenous people. (Fig. 9).

\section{THE ROLE OF THE VISITORS}

Museums are evolving and developing in most parts of the world, especially Indigenous oriented museums. This is in itself a buoyant time to think of new ways of exhibiting, to practice zones of contact, to make smaller and larger corrections to conventional ways of display. Many interesting perspectives about this point have emerged in the last decades, of relevance are the perspective of museum ethics
(Marstine 2011) and appropriate museology (Kreps 2008). Although most museum experts still are not from an Indigenous background, and despite one knows a lot about the artefacts on display, it is hardly enough to completely render the epistemologies and lived experience that created or constantly transformed them and re-installed their raison dêtre. One of the quests of the three exhibitions initiated by Tromsø University Museum, in retrospect, was of reflecting in different ways on such raisons d'être, and on their multiple systems of knowledge. In the questionnaires that we asked visitors to compile for both permanent exhibitions at the Tromsø University Museum, and from the conversations and dialogues we recorded in Sámi Stories, we have tried to grasp 
some of the important feedback that were generated in the fruition of these presentations.

What did the public experience in these three exhibitions? What type of interpretations do the visitors develop in the fruition of the representation of Sámi culture? How are the tactics deployed in negotiating meanings about the set-ups? What are the modalities in which these exhibitions succeed in problematizing or even disrupting assumptions from the visitors?

Samekulturen was meant for the Sámi to be visible, respected, proud, even if the presentation was somehow stereotyped and many people would not necessarily recognize themselves in it. Despite the nobility of Vorren's endeavor, the Sámi culture seems to be suspended in a time and space other than in Scandinavia where there is no mention of oppression, colonialization, and injustice, which the Sámi people have experienced over centuries. The exhibition addresses both Nordic and Sámi audiences, even if individual stories are not profiled and there are no "close up" displays where visitors could encounter individual Sámi perspectives. Sápmi - en nasjon blir til was instead an attempt to address the ongoing difficult communication between the two communities: Sámi and Norwegian. Among them, the consistent problems of identity, questioning Sámi belonging. The exhibition also illustrates that this ethnic group is heterogenous. Many of these difficult stories and experiences can be listened to in the interviews provided by the exhibition in three languages: Sámi, Norwegian and English. ${ }^{12}$ Those interviews bring us closer to the singular perspectives, equally presented in terms of language, political views, gender, work, age and regional Sámi background. Sámi Stories was conceived of for a foreign audience. It was a highly aestheticizing presentation, stressing the avant-garde aspects of Sámi art, the risk of commodification thereof, but also Sámi as a cutting-edge Indigenous people in many domains. It also shows some relevant close-ups, in the art-work and in videointerviews, through the accounts of two wellknown people among all Norwegian-Sámi, two internationally known "ambassadors" of art-music (Mari Boine) and Indigenous politics (Ole H. Magga). Their interviews have the flavor of confessional storytelling and assume that difficult stories are part of one's identity, material life, agency and that they feed the present.

The knowledge resting on images heavily conditioned by consumerist icons can be the background for many of the non-Sámi visitors that constitute the majority of the audience in these exhibitions. Reindeer herding, craft, traditional clothes, and nomadic implements are only some of the most popular standards that circulate in the domain of cultural consumption.

As anthropologist Kjell Olsen emphasizes (2003:7), the stereotypes that insist on the traditional culture end up affecting the ordinary life and manifest an asymmetric relation between a tourist and a generic Sámi "other" as well as between the representation of a supposed Sámi essence, against the assumptions defining Western society. Referring to these stereotypes, the experience of the audience in these exhibitions has demonstrated that the museums could be the authoritative arena to confirm such prejudices, or vice versa, to challenge them. Indeed, museums cannot avoid adhering to models of "packaged culture" diffused by the tourism market through stereotyped icons (Simonicca 2004:21). Despite this, the comments of the visitors show that they may also find elements to contest this representation, searching to 
148 understand who the Sámi people are and how they live. The current comments on the guest books and to the guides that also collected many of them can be considered as an example of this. Indeed, even if they are mainly judgements influenced by the filter of the cultural industry, they demonstrate ways to consider Samekulturen as an arena to learn new things about the past, as Ørnulf Vorren had wished.

In Sápmi - en nasjon blir til, the audiovisual devices, the conceptual design, and the symbolic cross-references that objects and themes propose, allow the visitors to come closer to the stories and events. Many visitors express compassion toward the accounts they hear in the video-interviews. The multiplicity of voices from spectators that have appreciated or dissented from the presentation are important indicators of how this set-up makes different categories of visitors feel more familiar with the subjects. If for Norwegians or Sámi people living in the region, the exhibit mostly reflects a narrative about events that are known, even though they are told with a deployment of political attributes, then for the foreign visitor the Sámi culture is rather a term of comparison to rethink the experiences of other known populations, or simply familiar and imagined ones. This approach generated both critical comments (like those of Argentinian visitors irritated by the presence of a Che Guevara's icon in the exhibition), but also comments that reflect a sense of solidarity on the part of visitors when comparing the ethnopolitical history of the Sámi movements with movements in Indigenous communities in Canada, Australia, New Zealand etc.

Following Stuart Hall (2006) and matching the moment of "encoding" of an ideal public (the one that knows well its local history) with the intentions of the curators, and the moment of the "de-coding" with the polyphony of voices of visitors (who mostly ignore local history), make the articulations of the exhibition even more complex and diverse. What happens is that, despite the intention of the curators to present the ethno-political process of emancipation of the Sámi people, many visitors appropriated the theme through a personal involvement based on the experience of cultural belonging, political positioning, and biographical events. These diverse outcomes were somehow unforeseeable by the curators.

The museum, as an "organizer of knowledge" cannot prescind from the public, for it is inevitably attracted in a hermeneutical circle as an integral component of the process of fruition (Ragazzi 2008). This was in fact one of the main museological concepts that Harald Eidheim highlighted when conceiving Sápmi - en nasjon blir til. The educational character of exhibitions can be summed up as follows: "Entering, one cannot see the whole world, but once out of the museum, one starts to discern something that was previously fragmented, learning to search further" (Clemente \& Rossi 1999).

Moreover, it is important to realize how exhibitions can contribute to images of the future, because museums often mainly present images of the past. Among the hundreds of comments collected over nearly twenty years in the Tromsø University Museum guest books, one , associated with Sápmi - en nasjon blir til, may say something about the longlasting effects it had on the public sphere: "May Norwegians and other Scandinavians continue to recognize Sámi rights!” Without reaching too far for a possible interpretation, this short incitement reminds the museum that, alas, it is mostly the responsibility of each State to safeguard Indigenous rights that took a century to be recognized. Without such a 


\section{Discourses, PRACTICES AND PERFORMANCES IN SÁMI museology at Tromsø University MUSEUm}

mandate, no ethnographic exhibition would represent the evidence of a long gone past, a past which is still very much living outside the walls of the museum.

\section{Notes}

1. Together with Harald Eidheim were Terje Brantenberg, Dikka Storm, Johan Albert Kaldstad, and Ivar Bjørklund.

2. For a more detailed analysis of Vorren's ideas and on his exhibition Samekulturen, the role of Tromsø Museum in the years before it became part of the university see Trude Fonneland's article, in this volume (2019). The book Samekulturen was newly re-edited in 1976 and translated into several languages.

3. Although Vorren was himself highly respected by many Sámi, having grown up in Sápmi and speaking North Sámi, he thought of ethnographic description as impartial and objective, not considering "subjective experiences".

4. Peter Vergo indicated with this concept the "state of widespread dissatisfaction with the 'old' museology, both within and outside the museum profession... what is wrong with the 'old' museology is that it is too much about museum methods, and too little about the purposes of museums..." (1989: 3)

5. Some of them were also militants during the Alta case, and they had written reports, media articles and books that addressed the questions for which the Alta's was the case in point.

6. Ivar Bjørklund and Terje Brantenberg were in particular influenced by such a paradigm, stemming from the theories of F.Barth, $\mathrm{H}$. Eidheim and R.Paine

7. The catalogue authored by Ivar Bjørklund in Norwegian, is translated in Sámi, German, Japanese, English, French and Italian.

8. In Norwegian the words are "folk" and "befolkning", this distinction being important because "People" is more conceptual and cohesive, while "population" more quantitative, and administratively inflected.

9. It is not a photo-montage, but it turns out, a staged event and a political performance as we are going to explain later.

10. In the exhibition Sápmi - en nasjon blir til the caption has not been updated. In fact, today that paragraph is named $₫ 118$. The text explaining the correction reads (original New Norwegian): "Dei statlege styres maktene skal leggje til rette for at den Samiske folkegruppa kan tryggje og utvikle Samisk språk, kultur og samfunnsliv". (Endra med grunnlovsvedtak 6 mai 2014 kunngjort med res. 9 mai 2014 nr. 613, vedtak 27 mai 2014 kunngjort med res. 20 juni 2014 nr. 778, innhalde til tidlegere $\$ 108$ står noi $\$ 118$, med aninnhaldether tidlegeresto i $\$ 110$ a.)

11. "Objets ambassadeurs" of the Centre Culturel Jean-Marie Tjibaou (CCT) of Noumea (New Caledonia).

12. They are also available in the website of the exhibition and in this current time when the Truth Commission about forced assimilation has been created and is at work, these interviews prove to be invaluable documents about this topic.

13. They are not simply stories that impose themselves as urban legends, but accounts that are experienced on the skin, in the heart, in the mind, on the pathways of the wind, in the harshness of the streets, by a séidi leaning on a remote fjord, or in an assembly with hundreds of Indigenous people at the FN permanent Forum.

14. Signed by Joanna K. and Richmond H., Ontario, Canada, 2013.

\section{REFERENCES}

\section{Exhibitions:}

1973. Samekulturen. Ongoing. Curator: Ørnulf Vorren.

2000. Sápmi - en Nasjon blir til. Ongoing. Curators: 


\section{Rossella Ragazzi \& Giacomo Nerici}

Terje Brantenberg; Ivar Bjørklund, Harald Eidheim, Johan Albert Kalstad, Dikka Storm. www.sapmi.uit.no Website resource opened in 2007. Editor: Terje Brantenberg.

2014. Sámi Stories: Art and Identity of an Arctic People. Curators: Marit A. Hauan and Charis Gullickson. Traveling Exhibition 2014-2016, produced by Nordnorsk Kunstmuseum og Tromsø Museum - Universitetsmuseet. Shown at Scandinavian House, New York; Anchorage University Museum; Tromsø University Museum.

\section{Interviews}

Rossella Ragazzi, interviews with Harald Eidheim (2006); Terje Brantenberg (2006, 2018), Ivar Bjørklund (2007); Marit A. Hauan (2018).

Giacomo Nerici, interviews with Rossella Ragazzi (2018), Ivar Bjørklund (2018).

Ole Henrik Magga, video-interview in Sámi Stories, by Marit A. Hauan and Rossella Ragazzi (2013). Mari Boine video-interview in Sámi Stories, by Marit A. Hauan and Rossella Ragazzi (2013).

\section{Literature}

Bjørklund, Ivar 2000. Sápmi - en nasjon blir til (Sápmi - Becoming a Nation). Tromsø: Tromsø Museum. Clemente, Pietro \& Emanuela Rossi 1999. Il terzo principio della museografia. Roma: Carocci.

Clifford, James 1988. The Predicament of Culture: Twentieth-Century Ethnography, Literature, and Art. Cambridge, Mass.: Harvard University Press. Clifford, James 1997. Routes: Travel and Translation in the Late Century. Cambridge, Mass.: Harvard University Press.

Eidheim, Harald, Ivar Bjørklund \& Terje Brantenberg 2012. "Negotiating with the public - Ethnographic museums and ethnopolitics." Museum \& Society $10: 2,95-120$.

Fabian, Johannes 1983. Time and the Other, How Anthropology Makes its Object. New York: Columbia University Press.

Fonneland, Trude 2019. "The exhibition
Samekulturen. A social actor at the Tromsø University Museum: Knowledge production, and shifting circumstances”. Nordic Museologi 3, 118-133.

Gullickson, Charis \& Sandra Lorentzen (eds.) 2014. Sámi Stories: Art and Identity of an Arctic People. Stamsund: Orkana.

Gullickson, Charis \& Herminia Wei-Hsin Din 2015. "Rethinking Sámi cultures in museums." Nordisk Museologi 2, 84-95.

Guttorm, Gunvor 1999. “Duodji/Sámi handicraft - A part of the whole. Gába 1, 37-39.

Hall, Stuart 1992. "The West and the Rest: Discourse and power." In Stuart Hall \& Bram Gieben (eds.). Formations of Modernity. Cambridge: Open University Press/Polity Press, 184-227.

Hall, Stuart 2006, "Codifica e decodifica." In Stuart Hall (ed.). Il soggetto e la differenza. Per unarcheologia degli studi culturali e postcoloniali. Roma: Meltemi, 66-83.

Hooper-Greenhill, Eilean (2003) "Nuovi valori, nuove voci, nuove narrative: l'evoluzione dei modelli comunicativi nei musei d'arte". In Simona Bodo (ed.). Il museo relazionale. Riflessioni ed esperienze europee. Torino: Fondazione G. Agnelli.

Johansen, Harry 2015. Det Samiske flagget. Govas. Blog: govas.no

Karp, Ivan \& Steven D. Lavine (eds.) 1991. Exhibiting Cultures: The Poetics and Politics of Museum Display. Washington DC: Smithsonian Institution Press.

Karp, Ivan, Christine Mullen Kreamer \& Steven D. Lavine (eds.) 1992. Museums and Communities: The Politics of Public Culture. Washington \& London: Smithsonian Institution Press.

Kreps, Christina 1998. "Museum-making and indigenous curation in Central Kalimantan, Indonesia." Museum Anthropology 22:1, 5-17.

Kreps, Christina 2003. Liberating Culture: CrossCultural Perspectives on Museums, Curation and Heritage Preservation. London: Routledge. Kreps, Christina 2008. "Appropriate museology in 


\section{Discourses, PRACTICES AND PERFORMANCES IN SÁMI museology at Tromsø University MUSEUm}

theory and practice." Museum Management and Curatorship 23:1, 23-41.

Lidchi, Henrietta 1997. "The poetics and politics of exhibiting other cultures." In Stuart Hall (ed.). Representation: Cultural Representations and Signifying Practices. London: Sage/Open University, 151-222.

Marstine, Janet (ed.) 2011. Routledge Companion to Museum Ethics for the Twenty-First Century Museums. London: Routledge.

Mathisen, Stein R. 2001. "Hvem forteller hva om 'det samiske'? Utstillingen Sápmi - en nasjon blir til på Tromsø museum." Tidsskrift for folkloristikk 30, 37-42.

Mathisen, Stein R. 2004. "Representasjoner av kulturell forskjell. Fortelling, makt og autoritet i utstillinger av samisk kultur." Tidsskrift for Kulturforskning 3:3, 5-25.

Nerici, Giacomo 2019. 'Volevamo indietro la nostra storia'. Percorsi, scenari e usi del passato tra i Sami in Norvegia. Master thesis, University of Turin.

Olsen, Bjørnar 2000. "Sápmi - en nasjon blir til?” Museumsnytt 5:6, 20-23.

Olsen, Kjell 2003. "The touristic construction of the emblematic Sámi.” Acta Borealia 20:1, 3-20.

Oskal, Nils 2014. "The character of the milk bowl as a separate world, and the world as a multitudinous totality of references." In Marit Anne Hauan (ed.). Sami Stories: Art and Identity of an Arctic People. Stamsund: Orkana Akademisk, 79-89.

Paini, Anna \& Matteo Aria (eds.) 2014. La densità delle cose. Oggetti ambasciatori tra Oceania e Europa. Pisa: Pacini.

Ragazzi, Rossella 2008. "Steps toward and analysis of 'Sápmi - Becoming a Nation' exhibition at Tromsø University Museum.” In Peter Aronsson \& Andreas Nyblom (eds.). Comparing: National Museums, Territories, Nation-Building and Change. NaMu IV, Linköping University, Norrköping, Sweden 18-20 February 2008. Linköping: Linköping University, 99-119.
Rhiannon, Mason 2006. "Cultural theory and museum studies." In Sharon Macdonald (ed.). A Companion to Museum Studies. Malden, Mass.: Blackwell, 17-32.

Shelton, Antony 2006. "Museums and anthropologies: Practices and narratives.” In Sharon Macdonald (ed.). A Companion to Museum Studies. Malden, Mass.: Blackwell, 64-80.

Simonicca, Alessandro 2004. Turismo e società complesse: Saggi antropologici. Roma: Meltemi.

Smith, Laurajane 2006. Uses of Heritage. London \& New York: Routledge.

Storm, Dikka \& Kjellaug Isaksen 2014. "DuodjiDáidda." In Marit Anne Hauan (ed.). Sámi Stories: Art and Identity of an Arctic People. Stamsund: Orkana, 91-102.

Vergo, Peter (ed.) 1989. The New Museology. London: Reaktion Books.

Vorren, Ørnulf \& Ernst Manker 1957. Samekulturen. En oversikt. Tromsø Museums skrifter vol. 5. Tromsø: Tromsø Museum.

Rossella Ragazzi, Associate Professor in Museum and Visual Anthropology rossella.ragazzi@uit.no

The Arctic University Museum of Norway UiT - The Arctic University of Norway P.O. box 6050 Langnes N-9037 Tromsø, Norway

Giacomo Nerici, PhD Candidate in Anthropology giacomo.nerici@gmail.com

Università degli Studi di Milano-Bicocca Piazza dell'Ateneo Nuovo, 1 20126, Milano, Italia 